\title{
FIRE CHARACTERISTICS OF POLYETHYLENE DUST
}

\author{
Marián ŠKVARKA ${ }^{1}$, Richard KURACINA ${ }^{1}$, Zuzana SZABOVÁ ${ }^{1}$ \\ ${ }^{1}$ SLOVAK University OF TeCHNOLOGY In BRATISLAVA \\ FACULTY OF MATERIALS SCIENCE AND TECHNOLOGY IN TRNAVA \\ INSTITUTE OF INTEGRAL SAFETY \\ ULICA JÁNA BOTTU 2781/25, 91724 TRNAVA, SLOVAK REPUBLIC \\ e-mail: marian.skvarka@stuba.sk, richard.kuracina@stuba.sk,zuzana.szabova@stuba.sk \\ Received 28 April 2021, Accepted 21 May 2021, Published 20 July 2021
}

\begin{abstract}
Dust is a product or by-product in many industries. To ensure effective measures of explosion prevention, it is necessary to know the fire properties of dispersed and settled dust. These parameters cannot be calculated, but can be determined on the base of measurements in standard equipment. The article deals with the measurement of fire properties of polyethylene. The values of the minimum ignition temperature of settled and dispersed dust (MIT) and the values of explosion characteristics of polyethylene dust cloud lower explosion limit (LEL), maximum pressure $P_{\max }$ and maximum rate of pressure rise $(\mathrm{dp} / \mathrm{dt})_{\max }$ were measured. The measurements were performed on the equipment according to the STN EN 80079-20-2: 2016 Standard Explosive atmospheres - Part 20-2: Material characteristics - Combustible dust test methods and according to the STN EN 14034 + A1: 2011 Standard Determination of explosion characteristics of dust clouds. The MIT of the settled dust was not determined (the sample melted), the MIT of the dispersed dust was $435{ }^{\circ} \mathrm{C}$. The maximum explosion pressure $P_{\max }$ reached 7.0 bar, and the maximum rate of pressure rise $d P / d t$ was 37.5 bar.s ${ }^{-1}$.
\end{abstract}

\section{Keywords}

Fire characteristic, dust cloud, dust explosion, polyethylene

\section{INTRODUCTION}

Wherever flammable dust is present, there is a potential risk of fire or explosion. With the help of high-pressure technology, low-density polyethylene is produced in the LDPE 4 production unit in Slovnaft a.s. (Slovakia). During its production, the generated explosive dust can cause a fire or explosion. To prevent damage, it is necessary to know the fire and explosion parameters of such polyethylene. Based on the fire characteristics, it is possible to prevent material damage and take effective explosion prevention measures. 


\section{Dust}

Dust occurs in two states: settled dust (airgel) and dispersed dust (aerosol). Dust consists of particles up to $500 \mu \mathrm{m}$ in size [1] that are formed in industrial practice mostly by mechanical means. As the particle size decreases, the explosiveness increases and the minimum ignition temperature (MIT) decreases. Particles smaller than $100 \mu \mathrm{m}$ are generally considered hazardous. Above $100 \mu \mathrm{m}$, the flammability and explosiveness of dust decreases rapidly [2].

\section{Combustion and explosion of dust}

The burning of polymers is a complex chemical chain reaction. The polymer decomposes at high surface temperatures and diffuses to the flame front where it completely decomposes into a monomer. At the top of the flame, the gases react exothermically with oxygen, forming a flame. During gas formation, the oxidation of the polymer surface has a significant effect on the combustion mechanism of the polymer [3].

A dust explosion requires five factors (Figure 1):

- fuel - dust,

- an oxidising agent,

- a source of ignition,

- mixing - swirling to form a dispersion,

- and an enclosed space [4].

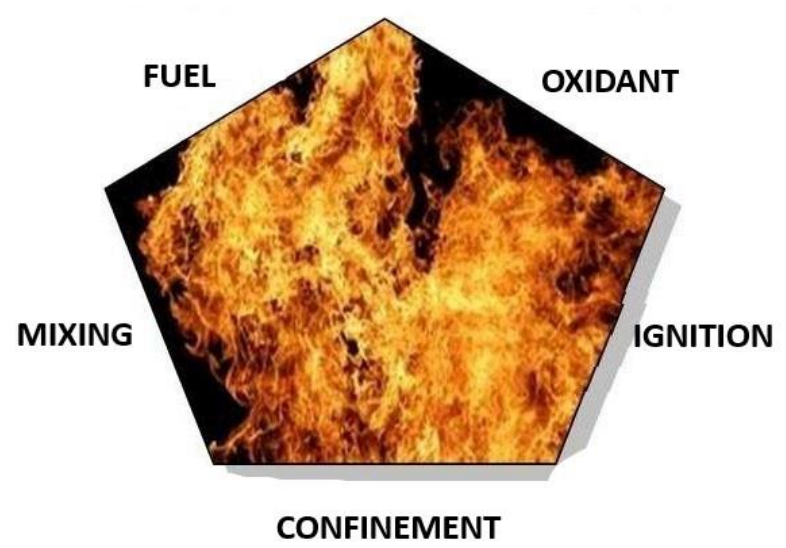

Figure 1 Explosion pentagon [5]

\section{Fire characteristics of dust}

Knowledge of fire characteristics is important for assessing the fire hazard of a material or product. Fire characteristics are numerical values that describe the behaviour of substances or materials during the formation and course of combustion until its termination [6]. In the experiment described in this article, selected characteristics of polyethylene dust were determined. The measurement results are shown in Tables 3 and 4. 


\begin{tabular}{|l|l|}
\hline \multicolumn{2}{|c|}{ Table 1 Fire characteristics of settled and dispersed dust [7] } \\
\hline Minimum ignition temperature of settled dust $\left[{ }^{\circ} \mathrm{C}\right]$ & \multicolumn{1}{c|}{ Dispersed dust } \\
\hline Flame rate $\left[\mathrm{mm} . \mathrm{s}^{-1}\right]$ & Minimum ignition temperature of dispersed dust $\left[{ }^{\circ} \mathrm{C}\right]$ \\
\hline Critical heat flux $\left[\mathrm{W} \cdot \mathrm{m}^{-2}\right]$ & Maximum explosion pressure [bar] \\
\hline Critical degradation temperature $\left[{ }^{\circ} \mathrm{C}\right]$ & Maximum rate of pressure rise $\left[\mathrm{bar} . \mathrm{s}^{-1}\right]$ \\
\hline Heat of combustion $\left[\mathrm{MJ} . \mathrm{kg}^{-1}\right]$ & Lower explosion limit $\left[\mathrm{g} \mathrm{m} \mathrm{m}^{-3}\right]$ \\
\hline Oxygen number $\left[\mathrm{Vol} . \% \mathrm{O}_{2}\right]$ & Limiting oxygen concentration $\left[\mathrm{Vol} . \% \mathrm{O}_{2}\right]$ \\
\hline
\end{tabular}

\section{MATERIALS AND METHODS}

A sample of low-density polyethylene dust came from the LDPE4 production unit of SLOVNAFT a.s. A dust sample was obtained from the silo which was cleaned by water during rinsing. The moisture content of the low-density polyethylene was $1 \mathrm{wt}$. $\%$. The melting point of LDPE is $100-120^{\circ} \mathrm{C}$. The sample was dried in a laboratory oven at $80^{\circ} \mathrm{C}$ for two weeks.

The proportion of dimensional fractions of the polyethylene sample is determined by sieve analysis. The analysis procedure was performed according to STN ISO 3310-1: 2007-03 (25 9610). The analysis was performed on Retsch AS 200, an automatic vibrating sieving machine. A set of stainless-steel sieves with the sieve openings described in Table 2 was used. The sieving time was $15 \mathrm{~min}$. with an amplitude of $2 \mathrm{~mm} / \mathrm{G}$. The results of the sieve analysis of the LDPE sample are shown in Table 2. The median value of $145 \mu \mathrm{m}$ was determined from the measured values.

\begin{tabular}{|c|c|}
\hline \multicolumn{2}{|c|}{ Table 2 Proportion of particles sizes in the sample } \\
\hline Particle size $[\boldsymbol{\mu m}]$ & Proportion of particles sizes in the sample [\%] \\
\hline all & 100.000 \\
\hline $0-500$ & 95.120 \\
\hline $0-250$ & 72.877 \\
\hline $0-200$ & 58.494 \\
\hline $0-150$ & 42.820 \\
\hline $0-90$ & 21.868 \\
\hline $0-71$ & 12.787 \\
\hline $0-56$ & 6.969 \\
\hline
\end{tabular}

MIT measurements of dispersed dust were performed on a standardized equipment, Godbert-Greenwald furnace, Figure 2. [8] Apparatus for MIT of dust layer consists of a heated plate and a dust ring $5 \mathrm{~mm}$ in height. The explosion parameters were determined in the $\mathrm{KV}$ $150 \mathrm{M} 2$ explosion chamber, Figure 3. 


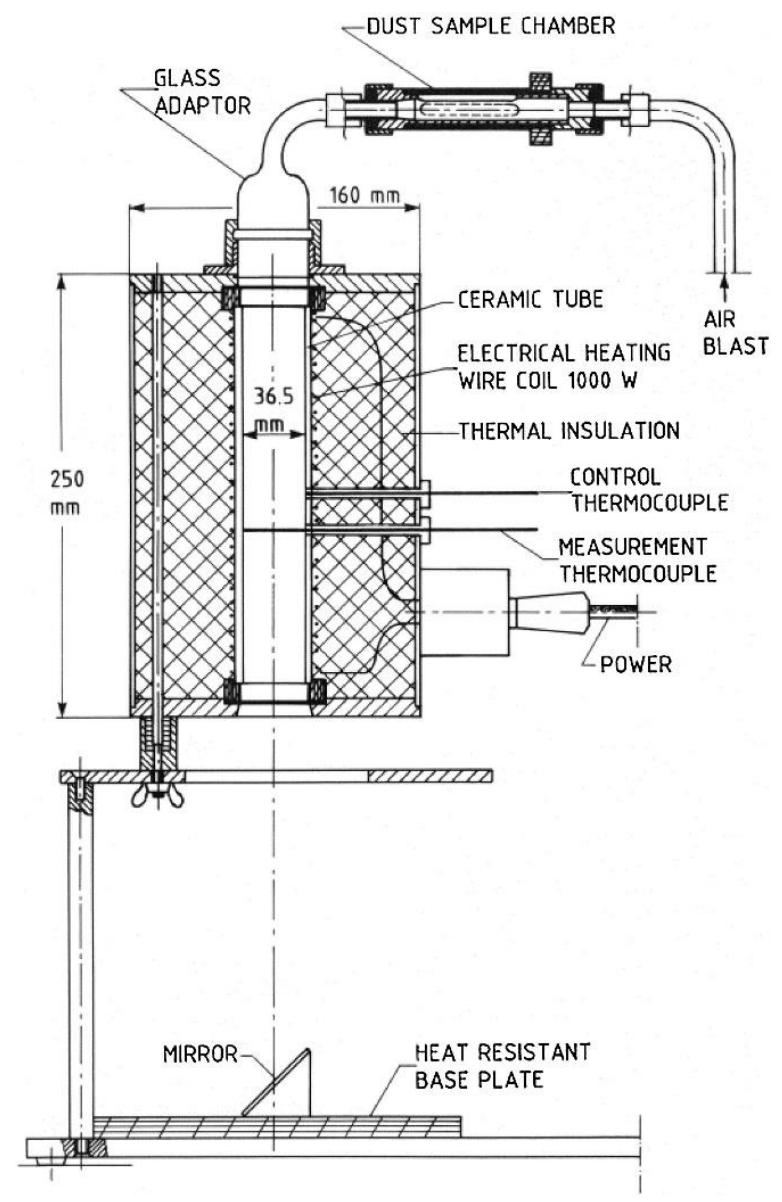

Figure 2 Godbert-Greenwald furnace for determination of minimal ignition temperature of settled dust [8]

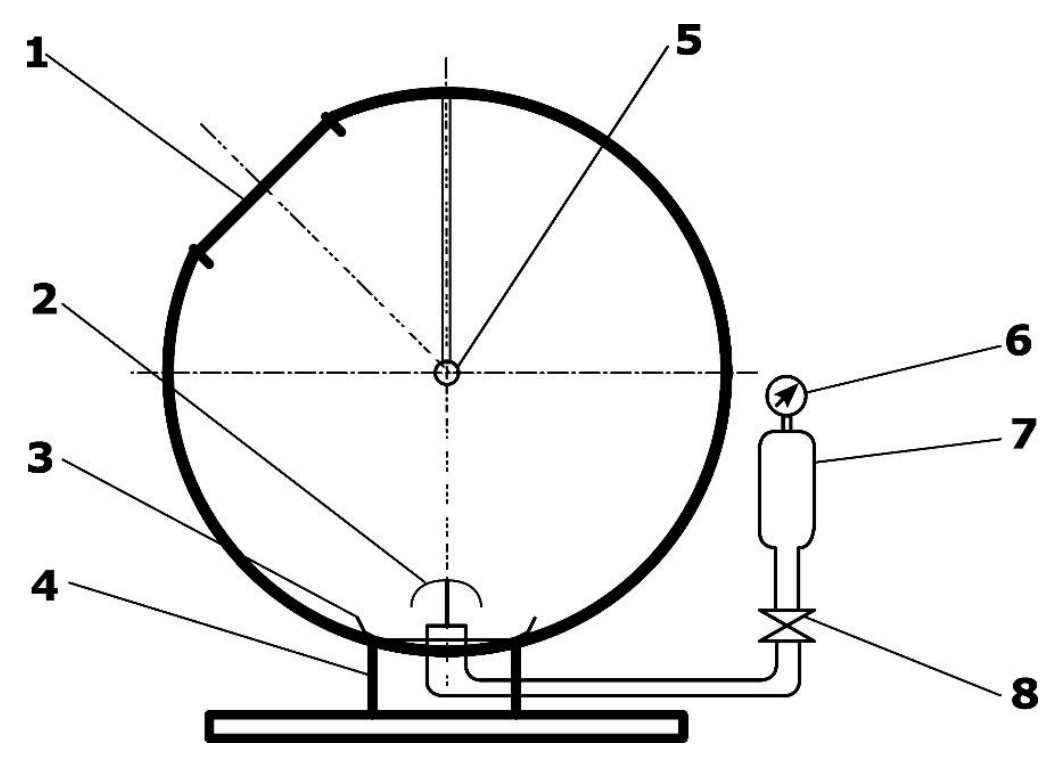

Figure 3 KV 150M2 explosion chamber (1 - lid, 2 - air flow reverser, 3 - dispersing plate, 4 - stand, 5 - igniter, 6 - manometer, 7 - air pressure vessel, 8 - dispersing valve) 


\section{RESULTS AND DISCUSSION}

The MIT of settled dust was measured according to the STN EN 80079-20-2:2016 Standard [9]. At 375,388 and $400{ }^{\circ} \mathrm{C}$, no decay and heating of the polyethylene sample was observed during the 30 minutes of measurement. The polyethylene sample melted at all temperatures.

Determination of MIT of dispersed dust was performed according to the STN EN 80079-20-2: 2016 Standard [9, 10]. Air pressures of $20 \mathrm{kPa}$ and $50 \mathrm{kPa}$ were used to disperse the sample. A sample of polyethylene dust was placed in the dust container. The MIT of the dispersed dust was measured at the furnace surface temperatures of 450, 455, 465 and $475^{\circ} \mathrm{C}$. The sample weight was calculated based on the highest value of the explosion pressure $\mathrm{P}_{\max }$. The highest value of the explosion pressure was reached at a concentration of $150 \mathrm{~g} . \mathrm{m}^{-3}$ and the optimal weight of the polyethylene sample was $0.04 \mathrm{~g}$. A polyethylene fraction of less than $71 \mu \mathrm{m}$ was used to determine the MIT of the dispersed dust. During the test, an explosion flame was observed at the lower end of the furnace tube.

The minimum ignition temperature was determined to be the lowest temperature of the furnace at which ignition occurred, reduced by $20{ }^{\circ} \mathrm{C}$. The minimum ignition temperature of the dispersed dust was $435^{\circ} \mathrm{C}$.

A KV 150M2 explosion chamber was used to determine the lower explosive limit of the sample, the maximum overpressure and the maximum pressure rise. The determination of explosion characteristics was performed according to the STN EN 14034 + A1: 2011 Standard [10]. The measurement was performed at the dust concentrations of $60,100,125,150,200,250$ and $500 \mathrm{~g} \cdot \mathrm{m}^{-3}$, Figure 4, Table 3. The value of the lower explosive limit (LEL) of the polyethylene sample is $60 \mathrm{~g} \cdot \mathrm{m}^{-3}$. The maximum value of the pressure at the explosion of 7.00 bar was at a concentration of $150 \mathrm{~g} . \mathrm{m}^{-3}$, Figure 5. The maximum value of the pressure rise during the explosion was 37.5 bar.s ${ }^{-1}$. The explosion constant $\mathrm{K}_{\mathrm{st}}$ has a value of 24.9 bar.m.s ${ }^{-1}$. Based on the $\mathrm{K}_{\mathrm{st}}$ value, the polyethylene sample was classified in class St 1 .

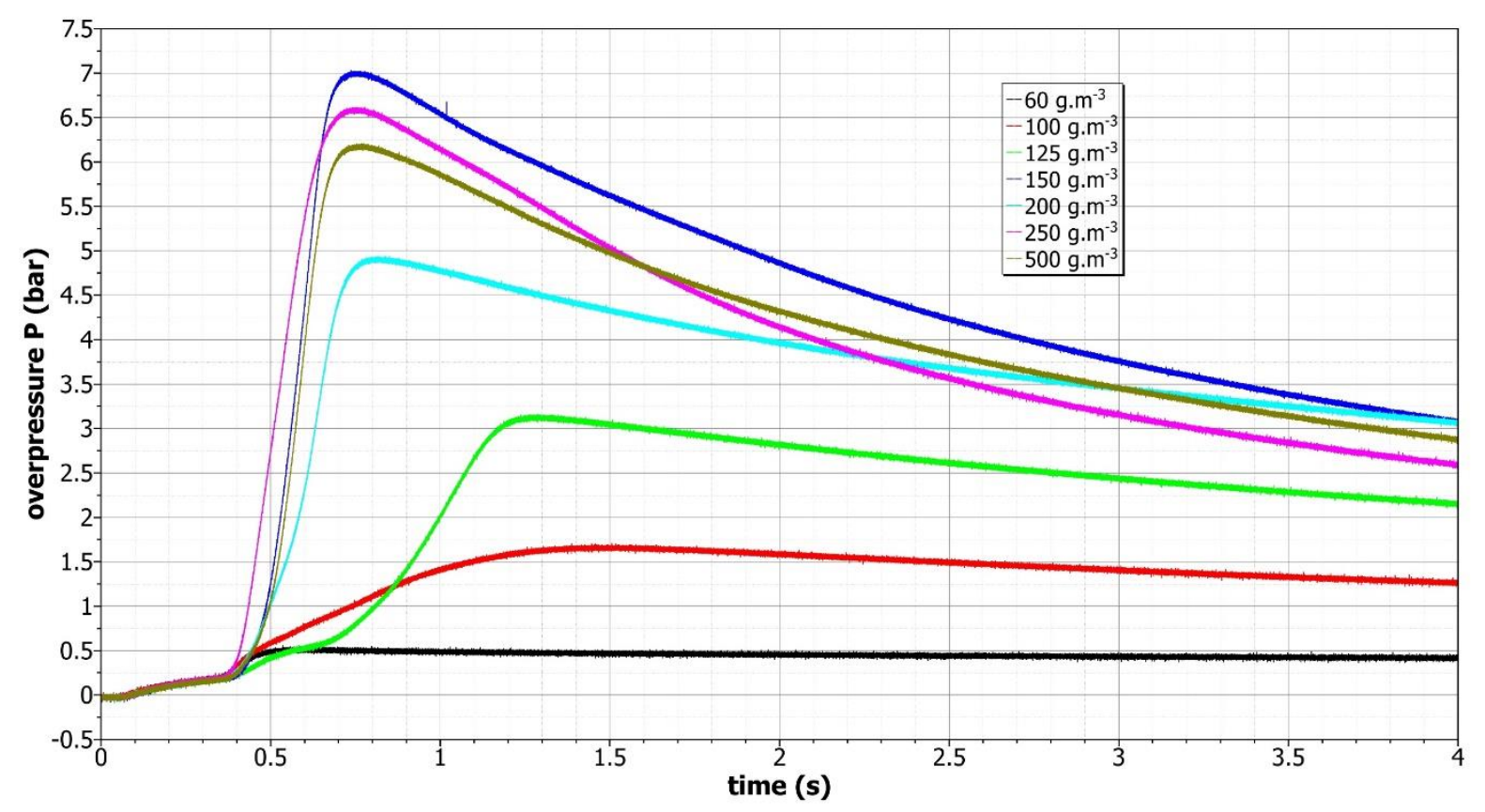

Figure 4 Maximum pressure of LDPE dust at concentrations 60, 100, 125, 150, 200, 250 and 500 g.m $\mathrm{m}^{-3}$ 


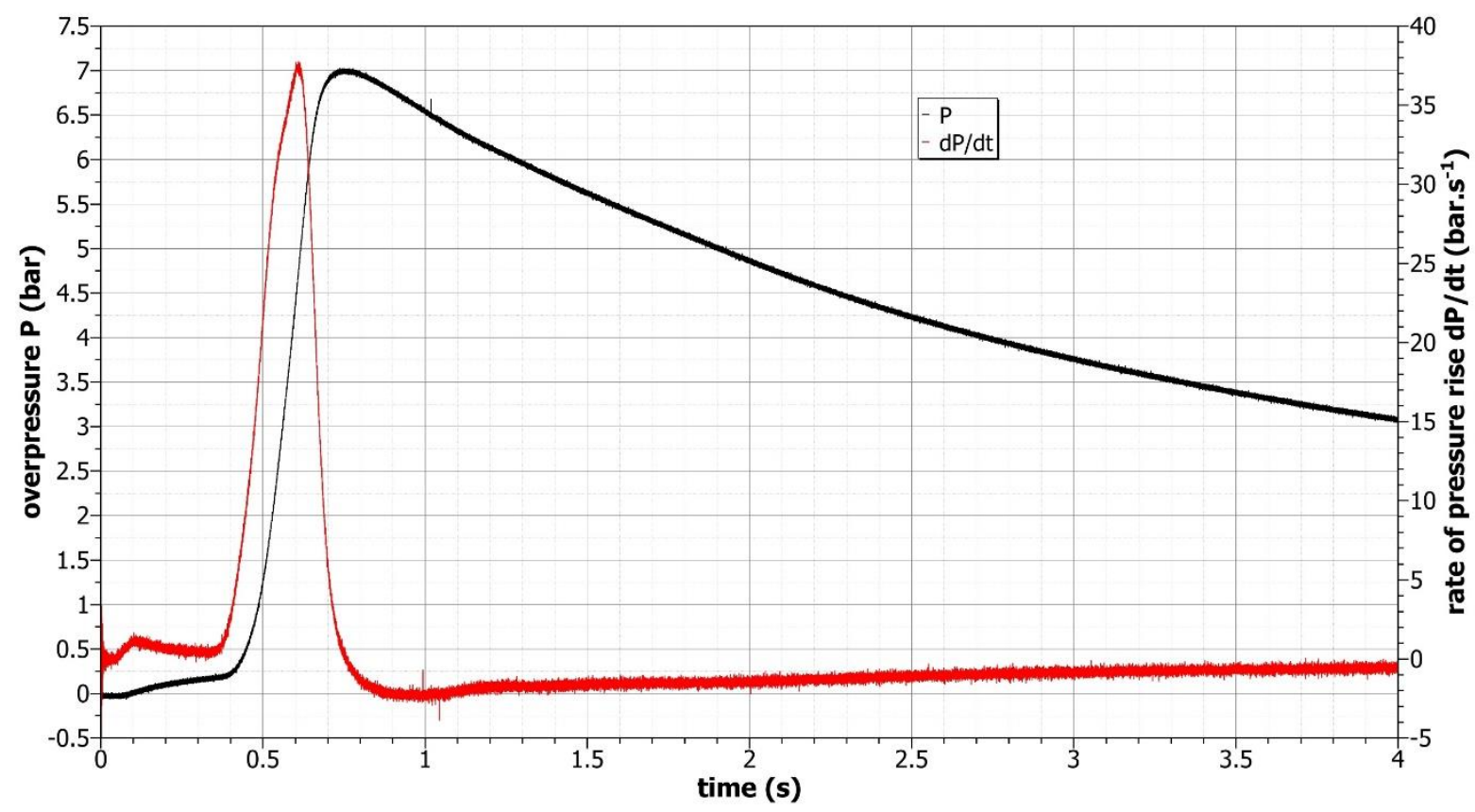

Figure 5 Maximum pressure rise rate and max. overpressure of LDPE dust at 150 g.m $\mathrm{m}^{-3}$

\begin{tabular}{|c|c|c|}
\hline $\begin{array}{c}\text { Concentration } \\
{\left[\text { g. } \mathrm{m}^{-3}\right]}\end{array}$ & $\begin{array}{c}\text { Overpressure } \mathbf{P} \\
\text { [bar] }\end{array}$ & $\begin{array}{c}\text { Rate of pressure rise } \mathrm{dP} / \mathrm{dt} \\
{\left[\mathrm{bar}^{\left.-\mathrm{s}^{-1}\right]}\right.}\end{array}$ \\
\hline 60 & 0.51 & $<1$ \\
\hline 100 & 1.65 & 3.60 \\
\hline 125 & 3.12 & 6.68 \\
\hline 150 & 7.00 & 37.50 \\
\hline 200 & 4.90 & 24.05 \\
\hline 250 & 6.59 & 27.58 \\
\hline 500 & 6.18 & 27.66 \\
\hline
\end{tabular}

The results obtained in the experimental determination of fire parameters of low-density polyethylene dust were compared with the table values in the IFA database [11] for low-density polyethylene dust (median 135, $150 \mu \mathrm{m}$ ), with the values given in MSDS Bralen and the values given in the explosion protection document for LDPE4 (Table 4). 


\begin{tabular}{|c|c|c|c|c|c|}
\hline $\begin{array}{l}\text { Fire technical } \\
\text { parameter }\end{array}$ & $\begin{array}{c}\text { Material safety } \\
\text { data sheet - Bralen } \\
+, \text { Slovnaft, a.s. }\end{array}$ & $\begin{array}{c}\text { Explosion prevention } \\
\text { document for LDPE4, } \\
\text { Slovnaft, a.s. }\end{array}$ & $\begin{array}{l}\text { IFA database, } \\
\text { median } 135 \mu \mathrm{m}\end{array}$ & $\begin{array}{l}\text { IFA database, } \\
\text { median } 150 \mu \mathrm{m}\end{array}$ & $\begin{array}{c}\text { Measured } \\
\text { results, median } \\
145 \mu \mathrm{m})\end{array}$ \\
\hline $\begin{array}{l}\text { Ignition temperature } \\
\text { of settled dust }\left[{ }^{\circ} \mathrm{C}\right]\end{array}$ & 350 & melts & melts & melts & melts \\
\hline $\begin{array}{l}\text { Ignition temperature } \\
\text { of dispersed dust } \\
{\left[{ }^{\circ} \mathrm{C}\right]}\end{array}$ & 445 & 350 & 470 & 480 & 435 \\
\hline $\begin{array}{l}\text { Maximum explosion } \\
\text { pressure [MPa] }\end{array}$ & - & 0.9 & 0.78 & 0.74 & 0.70 \\
\hline $\begin{array}{l}\text { Maximum pressure } \\
\text { rise rate }\left[\mathrm{bar} . \mathrm{s}^{-1}\right]\end{array}$ & - & - & - & - & 37.5 \\
\hline $\begin{array}{l}\text { Explosion constant } \\
\mathrm{K}_{\mathrm{st}}\left[\mathrm{MPa} \cdot \mathrm{m} \cdot \mathrm{s}^{-1}\right]\end{array}$ & - & 15.6 & 56 & 54 & 24.85 \\
\hline $\begin{array}{l}\text { Lower explosion } \\
\text { limit }\left[\mathrm{g} \cdot \mathrm{m}^{-3}\right]\end{array}$ & 100 & 16 & 60 & 125 & 60 \\
\hline Explosion class & - & - & St1 & St1 & St1 \\
\hline
\end{tabular}

\section{CONCLUSION}

Fire characteristics are important for the fire safety assessment. They are used for qualitative comparison of flammability and explosiveness of different dusts. Based on the fire characteristics, it is possible to propose effective measures to reduce the risk of explosion and fire.

By measuring fire characteristics of polyethylene sample we found that the MIT value of settled dust cannot be determined (polyethylene is melting), the MIT value of dispersed dust is $435{ }^{\circ} \mathrm{C}$, maximum explosion pressure is 7.00 bar, lower explosion limit is $60 \mathrm{~g} \cdot \mathrm{m}^{-3}$ and explosion value $\mathrm{K}_{\mathrm{st}}$ constant is 24.9 bar.m. $\mathrm{s}^{-1}$.

Comparison of the results with the data in the database and the MSDS shows that the measured values in each database vary. The differences between the measured values are due to the different properties of the polyethylene samples, e.g. particle size, degree of polymerization, etc.

\section{Acknowledgement}

This research was supported by the KEGA project 020STU-4/2021.

\section{References}

[1] LEES, F. 2005. Loss Prevention in the Process Industries, Vol. 2. Oxford, Elsevier, ButterworthHeinemann. ISBN 978-0408106979.

[2] DAMEC, J. 1998. Protivýbuchová prevence (Explosion prevention). 1998. $1^{\text {st }}$ edition SPBI SPEKTRUM 8. Ostrava: Sdružení požárního a bezpečnostního inženýrství (Association of fire and safety engineering), 288 p. ISBN 80-86111-21-0.

[3] MIDDLEMAN, S. 1977. Fundamentals of polymer processing. New York: McGraw-Hill College.. ISBN 978-0070418516.

[4] Eckhoff, Rolf, K. 2003. Dust explosion in the process industries. s.1. : Gulf Professional Publishing. ISBN: 0-7506-7602-7.

[5] ŠIMONÍKOVÁ, I. 2014. Zpuisoby ochrany před výbuchem - část 1 (Methods of explosion protection - part 1): Primárni protivýbuchová ochrana (Primary explosion protection). [cit.202001-02]. Available at: https://www.tzb-info.cz/pozarni-bezpecnost-staveb/10972-zpusobyochrany-pred-vybuchem-cast-1-primarni-protivybuchova-ochrana. 
[6] MAŠ̌́́K, I. 2003. Plasty a jejich požárni nebezpeči (Plastics and their fire prevention). OSTRAVA: Edice Spektrum SPBI. ISBN 80-86634-16-7.

[7] TUREKOVÁ, I. 2008. Význam požiarno-technických vlastností potravinárskych prachov v praxi. (Significance of fire properties of food dusts in practice.) In: Proc. Of VIII. Conference, Management of environment). Žilina: Strix et VeV. ISBN 978-80-89281-34-3.

[8] ECKHOFF R. K. 2019. Origin and development of the Godbert-Greenwald furnace for measuring minimum ignition temperatures of dust clouds, Process Safety and Environmental Protection, 129 p. $17-24$.

[9] STN EN 80079-20-2:2016 Explosive atmospheres - Part 20-2: Material characteristics Combustible dust test methods

[10] STN EN 14034+A1:2011 Determination of explosion characteristics of dust clouds.

[11] BECK H., GLIENKE N., MOHLMANN C. 1997. Combustion and explosion characteristics of dusts, Hauptverband der gewerblichen Berufsgenossenschaften, pp. 471. ISBN 3-88383-469-6.

\section{ORCID}

Zuzana Szabová

0000-0002-7886-1623

Richard Kuracina

0000-0003-1468-0820 